\title{
Boosting students' creativity in the EFL class through higher order thinking activities
}

\author{
Vidhya Pokhrel \\ Regent Residential School, Lalitpur, Nepal
}

\begin{abstract}
This article is a depiction of my concern in the implementation of higher order thinking activities in the EFL classroom. The article has explored the idea of higher order thinking along with its impact on students. Most importantly, it has given the scenario of how competent the teachers have to be in order to plan the lessons with higher order thinking activities. The article has picked up the real classroom scenarios where students came up with better output with higher order thinking activities. The content, the process and the product were all made the major concern in the article. Overall, the article develops an awareness on the exercise of higher order thinking activities in the EFL classroom.
\end{abstract}

Keywords: Higher order thinking, creativity, critical thinking, EFL, Bloom's Taxonomy

\section{Introduction}

Classroom is such a place where teachers encounter with children of different levels of thinking. Children in the classroom are of different abilities and therefore their thinking ability is also different. We want children to learn. Most often, we do not have the idea about why children are not learning. It might be because we as teachers are not skilled enough to give them opportunity to face higher order thinking skills. According to Saido, Siraj and Nordin (2015), higher order thinking skills can be improved by giving opportunities to students to think about their own thinking. They get to experience higher order skills if they are given opportunities. In fact, children's learning can be enhanced with higher order thinking activities.

\section{The Context: An Encounter with Higher Order Thinking}

With a view to putting the theme of the article into perspective, I begin with a personal account. Once, I was taking class at grade two. It was a substitution class. I thought it would be easy for me to handle the class if I engaged them in some work. I chose a very easy work that normally teachers choose when they have no plan or preparation for their class. I simply asked students to draw an apple and colour it. The students, with a great enthusiasm started their work. In about thirty minutes, they all 
finished drawing and colouring which they brought to me to check. While I was praising some of their work and giving them feedback, one of the students stood up and complained about her friend. Teacher! Look, she has coloured the apple half with green and half with red colour. Everybody laughed. As I asked them to be quiet, the same student uttered, Teacher! An apple should be red no... I went towards the student whose colouring was being criticized. I asked her, Ok tell me why you coloured this apple with both red and green. She replied, this apple is half ripen and half left to be ripening. Listening to her reason, I was perplexed. She was right. All apples may not be found ripen. I explained her logic to everyone and they were convinced. At this point, I thought, there are some students who have the higher order thinking skills. May be this girl was analyzing that particular stage of an apple while colouring. It may be that she was evaluating the apple and its ripening stage or maybe she was creating something with critical thinking Why do we colour the apple only red when we do have green apples in the market and also on my table? This girl triggered my thinking of higher order thinking in children.

\section{Higher Order Thinking}

Everybody wants children of the $21^{\text {st }}$ century to be problem solvers. There are some types of thinking that require greater cognitive processing. This thinking skill is necessary for problem solving. According to Zetriuslita, Ariawan \& Nufus (2016), problem solving is possible when there is critical thinking. Higher order thinking incorporates critical thinking as well as creative thinking where the learners work out to create something. The demand of today's society is the products that come out of creative and critical thinking. Furthermore, higher order thinking skills help students to conceptualize the things holistically and to reflect their creativity in their work (Shukla \& Dungsungnoen, 2016). Consequently, students can visualize a bigger picture when they are in the level of higher level thinking. Teaching strategies play a vital role in making students vigorous in higher level thinking. In other words, teachers need to be very much aware about giving higher order thinking tasks for students as higher level thinking tasks are totally in contrast with lower order tasks that comprise memorizing and translating. Ganapathy, Singh, Kaur \& Waikit (2017) claim that though it takes more time to implement higher order thinking skills in the lesson plan, it has positive learning outcomes. The implication of this is that teachers have to work hard for bringing higher order thinking and learning output in the class.

\section{Exploring the Real Classroom: a Step for Higher Order Thinking Activity}

Pohtola (2015) states that when students are asked to work in groups with the instruction that fits for that particular group, they can grasp the opportunity to learn better. Therefore, different activities can be implemented for different groups as per the level of thinking. Where they get to work with higher order activity, they can come up with their creative thinking.

\section{Course of Action}

King, Goodson and Rohani (1998) state that higher order thinking skills need good planning which has to be away from unrealistic expectations but has to have an appropriate instruction. Similarly, Tomlinson and Imbeau (2010) suggest that teachers can make instruction distinct through the categories: content, process and product. Being inspired by this, I developed a lesson plan including higher order activities to put to practise. I observed English as a Foreign Language (EFL) class 
at grade five. Data were collected from classroom where the higher order thinking activities were kept as instructions for students.

\section{Content}

This is where the information and skills are provided to students which they need to learn. The content was differentiated by designing the activities in level of Bloom's Taxonomy. I took hold of revised Bloom's taxonomy which focuses on the levels: remembering, understanding, applying, analyzing, evaluating and creating. These levels have carefully been spotlighted in the content that I developed. I designed plan for different groups who are supposed to work in different learning centers namely writing center, reading center, games center and creative writing center. In writing center, there was a task to remember what they are supposed to understand about Wright Brothers. In reading center, the students had the task to find the information about Wright Brothers from other reference books and to write. This was at the understanding level. Similarly, in games center, the task was to use flash cards to pick up the words related to invention and then to create a funny story out of those words. Thus, the task was in evaluation and applying level. It was to evaluate how much they have learnt from the lesson and how far they could reflect that in their story by applying the words they got. The other level included was the creating level as they had to create a story. Lastly, in the creative writing center, the task was in the creating level. This was the higher level of work where they had to write about the invention of their own. As everything was to be imagined and to write themselves, it was highly creative.

Focusing on home assignments they got, it was also based on different levels of thinking. The writing center was assigned the work in such a way that they had to go to the remembering level. It was to write answer of the given questions related to Wright Brothers. The reading center was assigned a task to collect the information from the Internet or from other reference books. Students were taken to the understanding level there. In games center, they were assigned work to make a paperairplane and write instruction for that. It was the creating level as well as analyzing level. Finally, the creative writing center was assigned with a task that they were supposed to construct something that is innovative. This was in the creating, applying and analyzing level. Bloom's taxonomy was properly exercised in the content that I developed.

\section{Process}

Different questions were asked Have you ever gone to the places using an aeroplane? Where did you go? The answers dropped from students' mouth were Bhairahawa, Hongkong, Pokhara and UK. Again, the question was asked, those who have not gone anywhere using an aeroplane, what is your feeling about it? The answers were scary, dangerous, interesting, etc. It shows that the students were making sense of what they were up to. Meaning making is an ability that enables students to use ideas intuitively (Bird, 2010). This is a level which uplifts learning. On day one, everybody was explained the chapter and were made to do the same task. They looked passive. The class was quiet and they did work as per the teachers' instruction. They were twisting their body, yawing though it was their first period, looking exhausted and looking at the watch time and again.

From day two, the students were sent to learning centers where they were to face activities which were in lower and higher order both. My participants were the particular group which was named as Group One. These students were normally 
counted as students of advanced level. I observed this group when they were in all four learning centers. On the day (day two), they were in the writing corner. As the instruction was to write about Wright Brothers, they started revising lessons in order to write something from there. The students were quiet in comparison to other groups. My focus was only on them. So, I kept on keeping my eyes upon them. I heard the voice somewhere in the group like Yes, it is in book, Do we copy it? It was a silent task where they need not to communicate. There was no curiosity in them. In the interview with Student1 the expression was that the students do not enjoy plain reading and writing task. The question was Do you enjoy reading and writing task or something interesting? The answer by Student1 was Something interesting like project works, 3D modelling.... For the same question, answer of Student 2 was Not reading and writing only... we have to do different activities. We have to learn something new... creativity.... This shows that students enjoy involving in higher level activities.

Third day, when Group Two was sent to the creative writing center, I saw a different spirit in children. My field notes have the contents such as Student 1 became thoughtful and said what shall I invent?as if she was inventing something real. The teacher asked, what do you like to invent? Nannybot, she said. The teacher asked, what is it? She answered; It is just like a robot that helps us to do household work. As my mother is busy, it could help her too. Interesting thing is that everybody in the group was talking about their invention. In that group, one boy wanted to create a pen that writes automatically without students' effort. The other girl wanted to write about a doll with all five sense organs. Next boy, a flying ladder so that he can fly in it and see the heaven and the other one, a flying bike in order to avoid traffic. Their discussion about the invention that they would like to make was amazing. I could see how little children wanted to get rid of the problems that they face in everyday life. Students were enthusiastic to write more about their creativity. Student1 asked Teacher! Can we write more with more ideas? With the answer yes, she looked pleased and other members of the group were also eager to write. For me, this was just a twist in the planning. It was the writing task. However, a little of their imagination brought a huge difference in the task.

The games center gave another excitement to these students. As they had to pick cards one by one and tell words they got, their sound started overcoming the sound of other groups. I could hear day and night, machine, successful, effort, manpower, experiment. A discussion turned into the noise but I could see how constructive their noise was. Everyone was giggling, speaking and accepting. They were refining the ideas to create the story. Student 1 and Student 2 were giving their input. Others were adding the ideas. In the midst, I heard You can write it was unuseful. Student1 immediately said I think unuseful is not the right word. Next student said oh.... useless, not unuseful. Student 1 said Hmm useless. Student 2 kept on writing. At last, they read their story in a group. They created a good story.

In the reading center, Group 1 just read book and wrote the points from there. They consulted other reference books and copied some points about Wright Brothers. No new was brought as they wrote the points from what they have read. I observed students' behaviour there. Student 2 was playing with his pen, Student 1 was double writing and her handwriting seemed worse, the other one was making a pair of his pen and started playing a drum-set. A good conversation went on between Student 1 and Student 2.

$\mathrm{S} 1$ : It is just to copy from here. (pointing to the book)

S 2: Yes. 
S 1: My hand is paining.

S 2: Mine too.

S 1: Two points more...Hyann...

S 2: Five number!! (looking at S1's notebook) and this is last.

\section{S 1: Already? I am in four number.}

Their focus was just to finish their work, not to learn something. They copied their homework and the class was over.

On the sharing day, I noticed that most of the students wanted to share what they had done in the creative writing center and the games center. Even in the interview with Student1, she said that she liked creative writing corner the most. She gave the reason saying because in the creative writing corner, we could write about our invention and how we feel about them and in games, we could use all of the words our friends collected and make a nice story. This shows that students enjoyed the interesting work in the corners.

\section{Product}

The activities were developed in such a way that the learners would demonstrate what they have learned. In the writing corner, the write up went in a way they were limited to the already learnt information. There were two brothers whose names were Orville and Wilbur. Orville was born in 1871 in Ohio and Wilbur was born in Indiana in 1867. They invented an airplane which could fly $812 \mathrm{ft}$ high and for fifty-nine seconds. In comparison to this writing product, the one that was produced in creative writing corner projects the freedom that the learners got in their work. Student1 went in this way. If I were an inventor, I would invent a useful thing like A Nanny Bot. A Nanny Bot is a robot that helps us in different things like: cleaning, cooking, washing etc. It would be proud. My neighbour would respect my invention. The leaner is more flexible, open up and free to write about her invention here. It boosted up her learning too.

Similarly, their product in the reading corner came up exactly as the points that were in textbook such as The longest flight of the day was only fifty nine seconds and distance only eight hundred and twelve feet. In contrast, the story that was created in the games corner using the words from the flash cards became a fun activity for them. They wrote Once in a small town, there lived some crazy inventors. They used to invent crazy machine without any effort. They worked day and night to make useless machine like flying toilet, soap that makes you dirty, powder that makes your face looked old etc. They were never successful...

They were having fun while they were in discussion time. It was a wonderful group work. Student 2 was interviewed with a question Do you think you become good in study just by reading and writing or by doing different activities like you did in the previous week? He answered, Not by reading and writing only. We have to do different activities. We have to learn something new... Again the question was asked, What type of class is the interesting class for you? He replied, The class where I can do new things. The product that came by the end of each class demonstrated that the students perform well when they are given the higher order thinking activities.

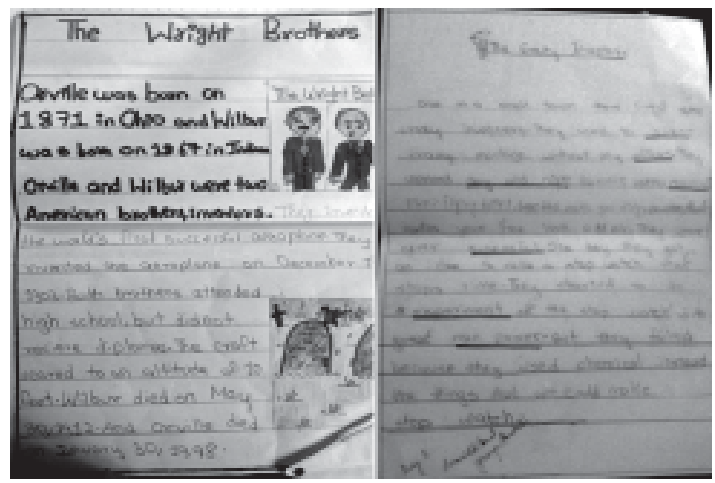




\section{Discussion of Findings and Implications}

The study was carried out in the whole class but the focus was in one group. It was observed that students, when kept in different learning centers for exercising higher order thinking activities and lower order thinking activities, make better effort in the higher order thinking activities. Abosalem (2016) concur that once the student obtains new knowledge and keeps that in his/her memory, he/she correlates, organizes and evaluates this knowledge for specific purpose and this is where they reach higher order thinking level. This point was kept in mind and the learners were kept in different corners each day to do different tasks, which were either of the level. This showed different level of performance in them. Overall, the classes went in different ways. In the whole class discussion day, everybody was excited to talk about creative writing center and games center. As I observed Group 1 as my participants, I found that the students did not enjoy writing center. They were yawning. They wanted to finish their work fast. It was just to copy. So, they mostly copied from book. . They did not look excited. Rather they were looking at other group's work. They did not ask any questions. They finished their work for the sake of doing.

In creative writing center, Student1 was sharpening her c o g n i t i o $n$. According to Eison (2010), when instructions are made for active learning, students get chance to think critically and creatively, grow in group work and

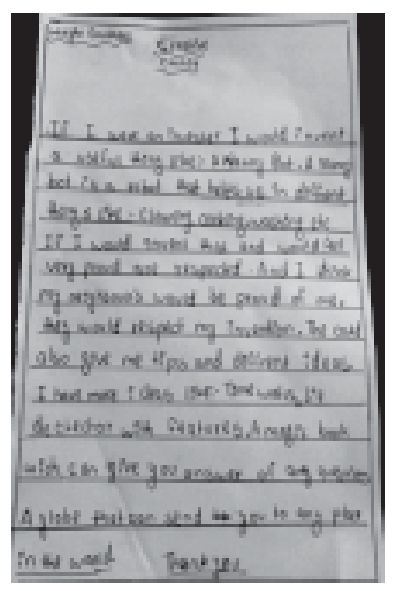

express their ideas by exploring their personal values and by reflecting upon their learning. Student1 said, What shall I invent? Later she said, she would like to invent Nanny Bot. She wanted to help her mother. So, she wanted to create Nanny Bot. She said, her mother is busy and Nanny Bot would help her do household work. I was amazed to see her level of thinking. She looked more enthusiastic.

In addition, the games center took these students to the level where they discussed and learnt something from their group. It was unuseful. One student said. The other said, I think unuseful is not the right word. Again, the other student said, Useless is the right word. They agreed. In reading corner, they projected like they did not enjoy. The outburst like My hand is paining, I am just in four number demonstrate that they did not enjoy their work. Their class behaviour, the product which they came with and their innocent expressions during class discussion show that they enjoyed much in creative writing center and games corner but were less interested in writing center and reading center.

My contemplation was that the students learn much better when they are given tasks of higher order thinking. Lee, Chao and Chen (2011) claim that interest can be generated in the classroom when the learning is meaningful and this makes learners active participants in the class. So, learning could be made meaningful by designing the tasks including higher order thinking. This has been clearly spotted in the classroom reality that I brought. Thus, higher order

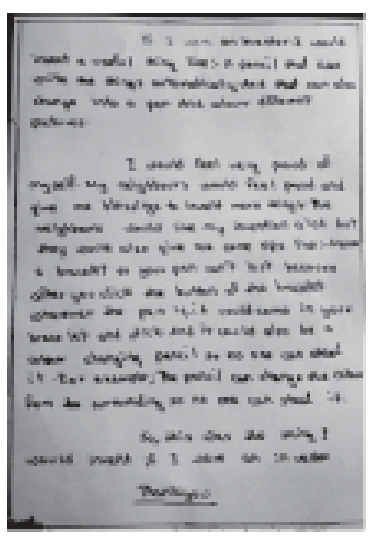


thinking activities can make difference in students' learning.

Human beings are of such characters and behaviours where they enjoy doing challenging tasks. To make their task challenging, teachers can think of including higher order thinking activities and it could be the finest way. The planning from teachers' side seems a bit thoughtful but the impact of the planned instruction is fruitful. This is what I exactly found in my small research towards implementing higher order thinking activities for my students.

As I indicated above, teaching higher order thinking/creative skills is a step-wise process. There are different activities to be developed and practised at different levels of the process. In a way of recommending teaching higher order thinking skills and assisting teachers in designing creative activities, the following figure of Level of Bloom's Taxonomy provides a list of activities that may be developed at different levels of teaching higher order thinking skills:
Figure 1. Level wise activities for teaching higher-order of thinking skills

(Source: https:// rachelmarsdenwords.files.wordpress.com/ $2014 / 10 / b_{10 o m s}$ t axonomy staircase.png)

It can be generalized that the higher order thinking activities are effective to teach EFL students to be creative. If teachers want, they can associate each student with their potential. They can make students creative and critical thinkers. To boost up students' learning, they have to be given the challenging tasks of higher order thinking where they can come up with their creativity and their critical thinking and thus learn with joy.

\section{References}

Abosalem, Y. (2016). Assessment techniques and students' higher order thinking skills.International Journal of Secondary Education, 4 (1), 1-11.

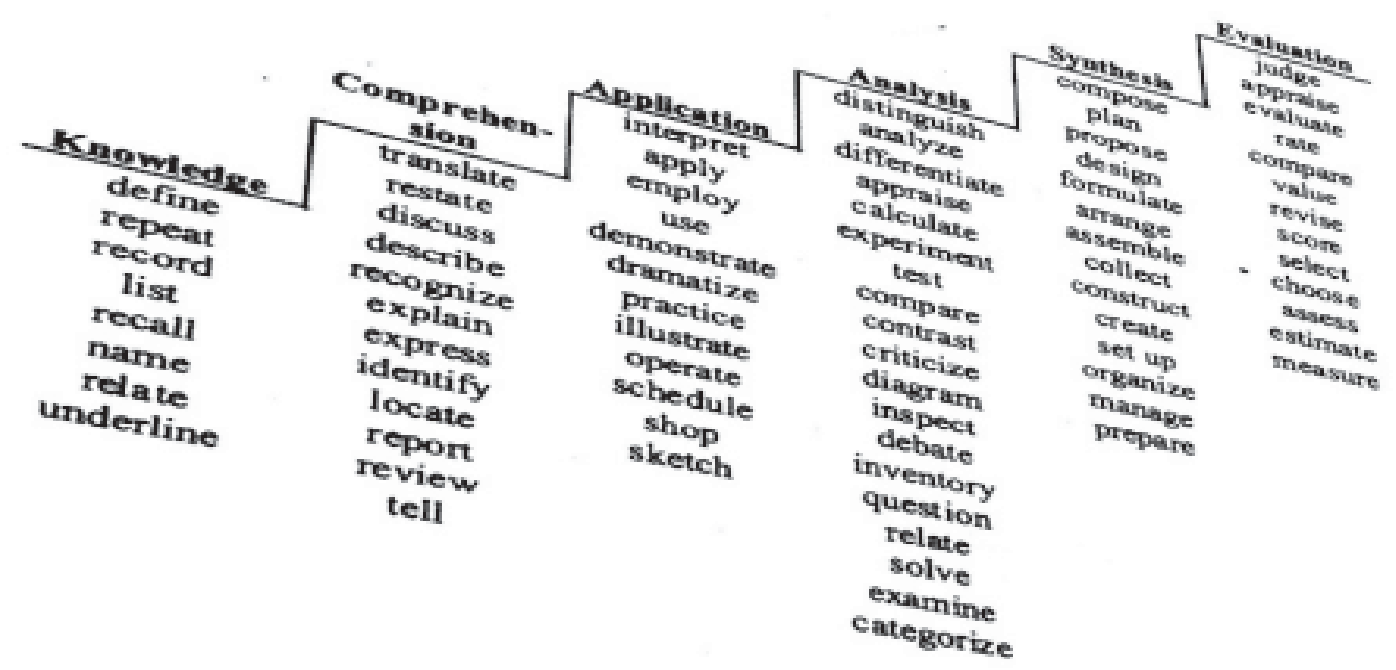


Bird, B. (2010). Meaning-making concepts: basic writer's access to verbal culture. Conference on Basic Writing. Retrieved from https:/ / bwe.ccny.cuny.edu/ Meaning-Making\% 20 Concepts$\% 20 \% 20$ Basic $\% 20$ Writer $\%$ E2 \% $80 \%$ 99s \% 20 Access $\% 20$ to $\% 20$ Verbal $\%$ 20Culture.pdf

Eison, J. (2010). Using active learning instructional strategies to create excitement and enhance learning. Florida: University of Florida.

Ganapathy, M., Singh, M.K.M., Kaur, S., \& Waikit, L. (2017). Promoting higher order thinking skills via teaching practices. The Southeast Asian Journal of English Language Studies, 23 (1), 7585.

King, F.J., Goodson, L., \& Rohani, F. (1998). Higher order thinking skills. Retrieved from http:/ / www.cala.fsu.edu

Lee, Y.J., Chao, C.H., \& Chen, C.Y. (2011). The influence of interest in learning and learning hours on learning outcomes of vocational college students in Taiwan: using a teacher's instructional attitudes as the moderator. Global Journal of Engineering Education, 13 (3), 140-153.

Pohtola, T. (2015). Differentiating instruction in EFL classrooms in secondary education. Retrieved from http:// www.fulbright.fi/sites/default/files/ Liitetiedostot/Stipendiohjelmat/ S $u$ o $\mathrm{m}$ a 1 a $\mathrm{i}$ s i $1 \mathrm{l}$ e / da_fy15_inquiry_project_pohtola_ finland.pdf

Saido, G.A.M., Siraj, S., \& Nordin, A.B. (2015). Teaching strategies scale for promoting higher order thinking skills among students in science. ISER Proceedings
Shukla, D., \& Dungsungnoen, A.P. (2016). Student's perceived level and teachers' teaching strategies of higher order thinking skills; a study on higher Educational institutions in Thailand.Journal of Education and Practice, 7 (12), 211-219.

Tomlinson, C. A., \& Imbeau, M. B. (2010). Leading and managing $a$ differentiated classroom. Alexandria, VA: ASCD.

Zertiuslita, H., Ariawan, R., \& Nufua, H. (2016). Students' critical thinking ability: Description based on academic level and gender. Journal of Education and Practice, 7 (12), 154-164.

\section{Contributor}

Ms. Vidhya Pokhrel is an M.Phil scholar in English Language Education at Kathmandu University. Currently, she is an academic coordinator in her own school. She has completed an education degree from U.K and accomplisheda number of professional trainingsin the field of education. 